East African Journal of Science, Technology and Innovation, Vol. 3 (1): December 2021

This article is licensed under a Creative Commons license, Attribution 4.0 International (CC BY NC SA 4.0)

\title{
Seroprevalence and risk factors of Neospora caninum and Bovine Viral Diarrhoea Virus in smallholder dairy cattle in Kenya
}

\author{
${ }^{1 *}$ VANLEEUWEN J A., ${ }^{1 M U R A Y A ~ J ., ~}{ }^{2}$ GITAU G K., ${ }^{3}$ MAKAU D N., ${ }^{1}$ CRANE M B., \\ ${ }^{1}$ MCKENNA S L B., ${ }^{4}$ WICHTEL J J.
}

\begin{abstract}
${ }^{1}$ Department of Health Management, Atlantic Veterinary College, University of Prince Edward Island, Charlottetown, Prince Edward Island, Canada.

${ }^{2}$ Department of Clinical Studies, Faculty of Veterinary Medicine, University of Nairobi, Nairobi, Kenya

${ }^{3}$ Department of Veterinary Population Medicine, University of Minnesota, St. Paul, USA

${ }^{4}$ Ontario Veterinary College, University of Guelph, Guelph, Canada

*Corresponding author: jvanleeuwen@upei.ca
\end{abstract}

\begin{abstract}
Little is known of the risk factors associated with occurrence of Neospora caninum and Bovine Viral Diarrhoea Virus (BVDV) infection in Kenya. This cross-sectional study hypothesized that there are significant biosecurity measures associated with $N$. caninum and BVDV infections on smallholder dairy farms in Kenya that could be adopted to reduce seroprevalence and impacts. From 158 randomly selected farms in Meru County, Kenya, 470 serum samples were collected from dairy cattle (over six months of age and unvaccinated for these two pathogens). Sera were analyzed for antibodies to N. caninum and antibodies and antigens to BVDV. Data on risk factors were obtained through face-to-face interviews with the farmers. Multivariable logistic regression models were used to identify significant risk factors associated with seropositivity for the pathogens. The apparent seroprevalence of $N$. caninum, BVDV antibody, BVDV antigen, and co-infection with N. caninum and BVDV antibody and/or antigen were $35.1 \%, 47.1 \%, 36.2 \%$ and $18.5 \%$, respectively. Risk factors associated with N. caninum antibody included: introducing milking cows into the farm, lending of cattle between farms, farm dogs having access to bovine aborted fetuses, and dogs whelping in the farm compound, with an interaction between the last two variables. BVDV antigen was associated with cattle having contact with pigs, and an interaction between cattle age and whether farms introduced new calves onto farms, and cattle age and whether visiting dairy farmers have access to the cow shed. Cows had higher odds of having BVDV antibodies compared to heifers. Factors associated with co-infection included cow parity, direct contact between dairy cattle, dogs and goats, and introducing new milking cows into the farms. Antibody and antigen results may be partly a function of classical swine fever virus or border disease virus interactions. Farmer education on these biosecurity measures is recommended, along with introduction of BVDV vaccination.
\end{abstract}

Keywords: Biosecurity; Diseases; Tropical Cattle; Veterinary Science; Farm Management

Cite as: VanLeeuwen et al., (2021) Seroprevalence and risk factors of Neospora caninum and Bovine Viral Diarrhoea Virus in smallholder dairy cattle in Kenya. East African Journal of Science, Technology and Innovation 3(1).
Received:

Accepted:

Published:

$28 / 07 / 21$

$02 / 12 / 21$

$17 / 12 / 21$ 


\section{Introduction}

Bovine viral diarrhoea virus (BVDV) and Neospora caninum protozoa are known to be among the most common agents of disease associated with reproductive disorders worldwide (Asmare et al., 2013). However, very little is known about the frequency and risk factors of these infections in East Africa (Okumu et al., 2019).

Domesticated and wild dogs are considered the definitive hosts for the N. caninum parasite, and several livestock and wild animal species have been identified as intermediate hosts (Donahoe et al., 2015). Horizontal transmission of N. caninum in cattle can occur through cattle ingesting feed, and water or soil contaminated with oocysts from infected dog feces. However vertical transmission by infection of fetuses in utero from infected dams is considered the primary transmission route (Kamali et al., 2014). Direct losses associated with $N$. caninum include lower milk yield in aborting cows and increased cow culling due to early embryonic death (EED) or abortions resulting from N. caninum, as well as reduced growth and feed efficiency in calves born alive (Dubey et al., 2007).

BVDV is endemic in many countries, with up to $60-85 \%$ of unvaccinated adult cattle being antibody positive, demonstrating exposure to the virus (Lindberg and Houe 2005). A majority of (acute) BVDV infections are inapparent, but the virus is responsible for reproductive problems, diarrhoea, immunosuppression and respiratory disease syndrome and therefore has considerable importance financially to the cattle industry (Yeşilbağ et al., 2017). In the first half of gestation, intrauterine infections could lead to EED, abortions or birth of persistently infected (PI) calves with no detectable antibodies (Fray et al., 2000). Infections during the second half of gestation could result in abortions, birth defects, still births, weak calves, or apparently normal calves, but not PI calves (Khodakaram-Tafti and Farjanikish 2017).

Neospora caninum and BVDV are both important abortifacient pathogens on their own, but synergistic effects of concurrent infections have been reported (Björkman et al., 2000). It is hypothesized that the immunosuppressive effects of BVDV increase the risk of fetal infection by $N$. caninum in pregnant cows, resulting to $N$. caninum abortions. Hence, investigating these pathogens simultaneously is valuable.

However, limited attention has been paid to these infections in East Africa, particularly in smallholder dairy farms (Yeşilbağ et al., 2017; Callaby et al., 2016). Olum et al., (2020) reported N. caninum antibodies in $24.1 \%$ of Kenyan dairy cattle. Kenyanjui et al., (1994) found a prevalence of $45.8 \%$ for BVDV in smallholder Zebu cows in the Kenyan coastal area, but that study did not identify any significant risk factors. Prevalence of $79.1 \%$ and $25.6 \%$ were recorded for BVDV and $N$. caninum, respectively, in large dairy farms in Rift Valley County of Kenya (Okumu et al., 2019). Over $80 \%$ of the cattle seropositive for $N$. caninum were also seropositive for BVDV in that study, but no significant risk factors of either infection were identified, even though neosporosis was found to be common in the farm dogs (Okumu et al., 2016). It is unclear how widespread these infections are in Kenya, especially within smallholder dairy farming systems (which constitute $80 \%$ of farms in the dairy industry in Kenya), or what factors are associated with infection.

The objective of this study was to determine the seroprevalence of these two pathogens and their associated factors in smallholder dairy farms in Kenya to identify evidence-based control strategies.

\section{Materials and methods}

\section{Study area and population}

The study was conducted in 2016 to 2017 in the Naari sub-location of Meru County, Kenya. This study area is located on the north-eastern slopes of Mount Kenya and borders the great Mount Kenya forest, approximately 2000 meters above sea level. It has daytime high temperatures ranging from $16^{\circ} \mathrm{C}$ during the cold season (JulyAugust) to $35^{\circ} \mathrm{C}$ in the hot season (JanuaryFebruary), and receives an average rainfall of 500 to $2600 \mathrm{~mm}$ each year (worldweatheronline.com). The study area is well-suited for small-scale dairy 
farming since it usually has sufficient precipitation and fertile soils. This region has no history of vaccination for BVDV or N. caninum.

The complete list of active member farmers of the Naari Dairy Farmers Cooperative Society (NDFCS) was obtained, and from these dairy farms, a list of 200 farmers was generated randomly through computer generated random numbers. The area covered by the NDFCS is divided into eight regions, and sampling was proportional to the total number of farms per region, producing a stratified random sample of farms. On each selected farm, up to 3 cows and 3 heifers older than six months of age were eligible for this study so that the overall results represent typical smallholder farmers in Kenya, without a bias toward larger farms. If farms had more than 3 cows or heifers, random sampling was used to identify which animals to include in the study.

\section{Data and sample collection}

Participating farms were visited in SeptemberOctober 2016 and March-April 2017, and blood samples were collected into labelled red top tubes with clotting agent (manufactured by Benton, Dickinson) from the coccygeal vein of eligible cows and heifers on the farm on the date of the farm visit. The March-April 2017 farm visits allowed for sampling heifers that were too young on the first visit, and other cattle that were not on the farm on the first visit (e.g. on community pasture, lent to another farm when feed supplies dwindled, or purchased since the first visit), up to the 3 cow and 3 heifer limit per farm. Physical exams (including body observation, thoracic auscultation, abdominal auscultation and percussion, and rectal temperature and palpation) were completed on the cattle prior to blood collection.

The collected blood samples were kept on ice during transport, and in the evening, allowed to stand and clot undisturbed at room temperature for 3-6 hours. The serum was transferred into serum vials and frozen at $-20^{\circ} \mathrm{C}$ until the time of laboratory analysis.

During the first visit, a questionnaire was also administered to the farmer during a face-to-face interview, and the information obtained included: animal and farm demographics (e.g. breed, age, breeding method, parity, and herd size), animal reproductive history, and questions about their management practices that were hypothesized as potential risk factors (e.g. whether it was possible that their cattle came into contact with other animals during the last year). On farms where cattle were sampled during both visits, the questionnaire was re-administered during the second visit for confirmation of the answers given during the first visit. Where the data differed between visits, the farmer was asked for the response that better represented the normal practices or circumstances of the farm.

\section{Laboratory analysis}

The serum samples were tested for antibodies to N. caninum, and antibodies and antigen for BVDV using commercial enzyme linked immunosorbent assays (ELISA) conducted at the University of Nairobi. For N. caninum exposure, the Neospora Ab Test ${ }^{\circledR}$ kit (IDEXX Laboratories, Switzerland) was used according to the manufacturer's instructions, which indicated a serum-to-positive $(\mathrm{S} / \mathrm{P})$ ratio equal to, or above, 0.5 was considered positive. According to the manufacturer, this kit is reported to have a sensitivity of $90 \%$ and specificity of $95 \%$.

The presence of BVDV antigen was tested with the BVDV Ag/Serum Plus Test ${ }^{\circledR}$ kit (IDEXX Laboratories, Switzerland), according to the manufacturer's instructions, which indicated an $\mathrm{S} / \mathrm{P}$ ratio above 0.3 was considered positive. According to the manufacturer, this kit is reported to have a sensitivity of $98.7 \%$ and specificity of $95 \%$ and can detect the majority of BVDV 1 and 2 antigens.

For BVDV antibody testing, the BVDV Total Antibody Test ${ }^{\circledR}$ kit (IDEXX Laboratories, Switzerland) was used according to the manufacturer's instructions, which indicated an $\mathrm{S} / \mathrm{P}$ ratio equal to, or above, 0.3 was considered positive. According to the manufacturer, this kit is reported to have a sensitivity of $100 \%$ and specificity of $95 \%$ and can detect the majority of BVDV 1 and 2 antibodies. The University of Nairobi laboratory staff were blinded to all the data on the tested animals. 
Data management and analysis

Data were entered and organised in an Excel spreadsheet (Microsoft, Sacramento, California, USA). The unit of analysis was seropositivity for the two pathogens for each individual animal in the farm at the time of sampling. Descriptive statistics (seroprevalence, mean, standard deviation, 95\% confidence interval - CI) for the animal- and farm-level variables were calculated, and analytical statistics assessing factors associated with infection (below) were conducted using STATA/IC 13.0 (StataCorp LLC, College station, Texas, USA). With the imperfect sensitivities and/or specificities of the laboratory tests used, all seroprevalence estimates were considered apparent prevalence.

Significant risk factors associated with infections of $N$. caninum and BVDV were determined through multivariable logistic regression models through the steps in the next paragraph. In total, four models were fit to determine: 1) risk factors of $N$. caninum antibody seropositivity; 2) risk factors of BVDV antibody seropositivity; 3) risk factors of BVDV antigen seropositivity; and 4) risk factors of co-infection of both pathogens (antibody positive to N. caninum and positive to antibodies and/or antigen to BVDV).

In the first step of the modeling, relationships between each outcome variable and the independent variables were individually investigated. In the second step, any variables that were associated at the $\mathrm{p}<0.15$ level were eligible to be included in the multivariable models. Pearson correlation coefficients between independent continuous variables were examined for those meeting the cut-off level to determine correlations $(-0.3<\mathrm{r}<0.3)$ among these variables that would be important during the multivariable regression analyses. Chi squared tests between independent categorical variables were examined for those meeting the cut-off level to determine associations among the variables that would be important during the multivariable regression analyses. For highly correlated variables, such as age and parity, where both variables would not be retained in the final model, the variable with the strongest significant association in each model was considered for the multivariable modeling, also considering biological plausibility where relevant. Both forward stepwise and backward elimination regressions were used to identify the most parsimonious model in which all independent variables remained significant at the $p<0.05$ level. Other variables not in the final model were examined for confounding of the variables in the final model, as recommended by Dohoo et al., (2009). Interactions between significant variables in the final model were investigated. Model fit was examined by checking the standard residual diagnostics, performing predictions, and examining the predictive ability of the models. Clustering of cattle within farms was assessed through intra-class correlations. Where the intraclass correlation was over $25 \%$, the model was run as a mixed logistic regression model with a random effect included for cattle clustered within farms, while the other regressions were run as ordinary logistic regression models with robust errors.

\section{Results}

\section{Seroprevalence}

A total of 470 cattle from 158 farms were blood sampled and available for testing for $N$. caninum and BVDV infections. Table 1 shows the number of sampled animals and farms by region. Region 2 showed the highest number of animals and farms sampled. Reasons for some of the 200 farms not being in this study included: no available milking cows or heifers at the time of the visit (on community pasture), unwillingness to participate in the project, and lack of availability due to death in the family or relocation out of the study area. Fewer samples were tested for BVDV than $N$. caninum because some blood samples provided a small volume of serum (and samples were tested for N. caninum antibody first, then BVDV antigen, and then BVDV antibody) and there were logistical problems with samples in storage. Therefore, 467 samples were tested for BVDV antigen, 323 samples were tested for BVDV antibody, and 469 sample were tested for either BVDV antibody or antigen $(n=469)$. 
Table 1. Distribution of animal and farm numbers and seroprevalence of Neospora caninum and bovine viral diarrhoea virus (BVDV), by region, on 158 smallholder dairy farms in Kenya in 2016-17

\begin{tabular}{lllllll}
\hline Region & Farms & Animals & $\begin{array}{l}\text { BVDV Ag } \\
\text { proportion } \\
\text { positive }\end{array}$ & $\begin{array}{l}\text { BVDV Ab } \\
\text { proportion } \\
\text { positive }\end{array}$ & $\begin{array}{l}\text { Neospora Ab } \\
\text { proportion } \\
\text { positive }\end{array}$ & $\begin{array}{l}\text { Coinfection } \\
\text { proportion } \\
\text { positive }\end{array}$ \\
\hline 1 & 15 & 45 & 0.227 & 0.563 & 0.378 & 0.244 \\
2 & 36 & 111 & 0.445 & 0.532 & 0.405 & 0.216 \\
3 & 25 & 74 & 0.411 & 0.463 & 0.338 & 0.149 \\
4 & 9 & 20 & 0.100 & 0.333 & 0.200 & 0.100 \\
5 & 21 & 69 & 0.420 & 0.569 & 0.449 & 0.290 \\
6 & 13 & 41 & 0.293 & 0.227 & 0.268 & 0.146 \\
7 & 9 & 30 & 0.233 & 0.176 & 0.433 & 0.033 \\
8 & 30 & 80 & 0.375 & 0.600 & 0.238 & 0.125 \\
\hline
\end{tabular}

The apparent seroprevalence for BVDV antibody was $47.1 \%(152 / 323)(95 \% \mathrm{CI}=40.7 \%-51.6 \%)$. The apparent seroprevalence for BVDV antigen was $36.2 \%(169 / 467)(95 \%$ CI $=31.9 \%-40.6 \%)$. There were $25.1 \%(81 / 323)$ of cattle positive for both BVDV antibody and antigen. Of the 163 cattle testing positive for BVDV antigen and having an antibody test result, $49.7 \%$ were also BVDV antibody positive. Table 1 shows the animal-level seroprevalences of BVDV antibody and antigen by region. Regions 2 and 5 had the highest BVDV seroprevalences. From the physical examinations carried out on all the cattle, only $7.9 \%$ were clinically ill at the time of sample collection, with signs of either pneumonia, diarrhea or mastitis.

The seroprevalence of $N$. caninum in this area was $35.1 \%(165 / 470)(95 \% \mathrm{CI}=30.9 \%-39.5 \%)$. There were $18.5 \%(87 / 469)(95 \% \mathrm{CI}=15.2 \%-22.3 \%)$ of the samples testing positive for both $N$. caninum and BVDV when either of the BVDV tests was positive (co-infections). Table 1 shows the animallevel seroprevalences of $N$. caninum and coinfection by region. Region 5 had the highest $N$. caninum and co-infection seroprevalences.

Of the 165 animals found positive for $N$. caninum, $20.6 \%(34 / 165)$ had a reported abortion in the past five years. Twenty percent $(34 / 169)$ of the cows that were seropositive for BVDV antigen had a reported abortion in the last five years, while this number was just slightly higher for BVDV antibodies at $23.6 \%(36 / 152)$. Of the 87 animals with co-infection for both these pathogens, $23 \%$ $(20 / 87)$ had a reported abortion in the last five years.

Demographic and univariable risk factor analysis

Univariable associations to prevalence of $N$. caninum and/or BVDV were assessed at a cut-off point of $p<0.15$. Seven, nine, four and six predictors were found to be individually associated with $N$. caninum, BVDV antigen, BVDV antibody and co-infection, respectively. The seroprevalence of $N$. caninum, BVDV antibody, BVDV antigen, and co-infection, by categories for the categorical variables that met the cut-off point, are shown in Tables 2 (cowlevel) and 3 (farm-level).

The overall mean age ( \pm standard deviation) of the whole sample population was $5.6 \pm 0.15$ years, ranging between 0.5-17 years. Compared to older cattle (3.5-8.5 years and $\geq 9$ years), young stock ( $\leq$ 3 years old) had a lower seroprevalence of BVDV antibodies and co-infection with both $N$. caninum and BVDV (either antibody and/or antigen) (Table 2).

Parity ranged from 0 to 9 , with a mean of 2.2. The majority $(61.7 \%)$ of cattle were in the $1-3$ parity group. Similar to age, compared to other parity groups (Table 2), nulliparous cattle had a lower 
seroprevalence of BVDV antibodies and coinfections with both $N$. caninum and BVDV (either antibody and/or antigen).

Table 2. Descriptive statistics and univariable associations of categorical cow-level risk factors for seroprevalence of Neospora caninum and bovine viral diarrhoea virus (BVDV) on 158 smallholder dairy farms in Kenya in 2016-

\begin{tabular}{|c|c|c|c|c|c|c|c|c|c|}
\hline \multirow{2}{*}{$\begin{array}{l}\text { Categories of certain } \\
\text { hypothesized risk } \\
\text { factors } \\
\text { Age of tested animal (yrs }\end{array}$} & \multirow{2}{*}{$\begin{array}{r}\text { Number }(\%) \\
\text { within } \\
\text { each category } \\
(\mathrm{n}=470)\end{array}$} & \multicolumn{2}{|c|}{$\begin{array}{l}\text { Positive }(\%) \\
\text { to } N \text {. caninum } \\
(\mathrm{n}=470)\end{array}$} & \multicolumn{2}{|c|}{$\begin{array}{l}\text { Positive (\%) to } \\
\text { BVDV antigen } \\
(\mathrm{n}=467)\end{array}$} & \multicolumn{2}{|c|}{$\begin{array}{l}\text { Positive }(\%) \text { to } \\
\text { BVDV } \\
\text { antibody } \\
(\mathrm{n}=323)\end{array}$} & \multicolumn{2}{|c|}{$\begin{array}{l}\text { Co-infection } \\
(\%) \text { to BVDV } \\
\text { and } N . \text { caninum } \\
(\mathrm{n}=469)\end{array}$} \\
\hline & & & & & & & & & \\
\hline$<3.0$ & $123(26.2)$ & $38 / 123$ & (30.9) & $35 / 122$ & $(28.7)$ & $19 / 83$ & $(22.9)$ & $12 / 123$ & $(9.7)$ \\
\hline$\overline{3} .5-8.5$ & $273(58.1)$ & $100 / 273$ & (36.6) & $107 / 273$ & (39.2) & $103 / 189$ & (54.5) & $55 / 273$ & (20.1) \\
\hline$>9.0$ & $74 \quad(15.7)$ & $27 / 74$ & (36.5) & $27 / 72$ & (37.5) & $27 / 51$ & (52.9) & $20 / 74$ & $(27.0)$ \\
\hline P-value ${ }^{1}$ & & 0.523 & & 0.129 & & $<0.005$ & & 0.006 & \\
\hline \multicolumn{10}{|l|}{ Parity } \\
\hline 0 & $84(17.9)$ & $23 / 84$ & $(27.4)$ & $18 / 83$ & (21.7) & $6 / 59$ & $(10.2)$ & $6 / 84$ & (7.1) \\
\hline $1-3$ & $290(61.7)$ & $108 / 290$ & $(37.2)$ & $118 / 290$ & $(40.7)$ & $108 / 200$ & $(54.0)$ & $56 / 290$ & (19.3) \\
\hline$\geq 4$ & $96(20.4)$ & $34 / 96$ & $(35.4)$ & $33 / 94$ & $(35.1)$ & $35 / 64$ & $(54.7)$ & $23 / 96$ & $(24.0)$ \\
\hline P-value 1 & & 0.254 & & 0.006 & & $<0.005$ & & 0.006 & \\
\hline \multicolumn{10}{|l|}{ Breed $^{2}$} \\
\hline Friesian & $216(46.0)$ & $72 / 216$ & (33.3) & $88 / 214$ & $(41.1)$ & $70 / 153$ & $(45.8)$ & $42 / 216$ & (19.4) \\
\hline Ayrshire/Jersey & 83 (17.6) & $30 / 83$ & (36.1) & $21 / 83$ & (25.3) & $28 / 55$ & (50.9) & $14 / 83$ & (16.9) \\
\hline Guernsey & $133(28.3)$ & $49 / 133$ & (36.8) & $42 / 132$ & $(31.8)$ & $38 / 88$ & (43.2) & $20 / 133$ & (15.0) \\
\hline Zebu & $38 \quad(8.1)$ & $14 / 38$ & $(36.8)$ & $18 / 38$ & $(47.4)$ & $13 / 27$ & $(48.1)$ & $9 / 38$ & $(23.7)$ \\
\hline P-value ${ }^{1}$ & & 0.905 & & 0.022 & & 0.705 & & 0.400 & \\
\hline
\end{tabular}

${ }^{1}$ Bold P-values indicate those meeting the criteria for multivariable modeling $(p<0.15)$

${ }^{2}$ There were no pure breeds of Friesian,Ayrshire/Jersey and Guernsey; they were all crosses with native breeds

Friesian crosses were the most common genotype in the sample population at $46.0 \%$ of the sampled animals. The exotic breeds in the area were not pure breeds and therefore are all reported as crosses, which was identified by a smaller body than expected but color markings that indicated the primary breed reported. Friesian crosses and Zebus had a higher seroprevalence of BVDV antigen than the other breeds (Table 2).

In this area of Kenya, just over half (55.1\%) of the cattle were free-roaming for some hours of the day to graze in the household compound (partial zero-grazing) or were grazed out on communal pastures along the roadside or in the forest (Table 3). There was no significant difference in the seroprevalence of the pathogens among the different grazing management groups, although for BVDV antibody, this feeding management practice met the cut-off point for multivariable modeling.

A total of $7.6 \%$ of the farmers indicated lending animals to other farmers during the last year. The variable was a significant univariable risk factor for seroprevalence of $N$. caninum, BVDV antigen and co-infection, respectively (Table 3 ).

Two-thirds $(67.5 \%)$ and a fifth $(20.4 \%)$ of the farmers indicated buying and introducing milking cows and calves into their farms in the last year, respectively. There was a positive univariable association at the cut-off of $\mathrm{p}<0.15$ between farmers that indicated buying and introducing milking cows into their farms and seropositivity of $N$. caninum, BVDV antigen and co-infection of the two pathogens. 
Table 3. Descriptive statistics and univariable associations of categorical farm-level risk factors during the last year for seroprevalence of Neospora caninum and bovine viral diarrhoea virus (BVDV) on 158 smallholder dairy farms in Kenya in 2016-17.

\begin{tabular}{|c|c|c|c|c|c|c|}
\hline $\begin{array}{l}\text { Categories of certain } \\
\text { hypothesized risk factors }\end{array}$ & $\begin{array}{l}\text { Number }(\%) \\
\text { within each } \\
\text { category } \\
(\mathrm{n}=470)\end{array}$ & $\begin{array}{l}\text { Positive }(\% \\
\text { N. caninun } \\
(\mathrm{n}=470)\end{array}$ & & $\begin{array}{l}\text { Positive }(\%) \\
\text { to BVDV } \\
\text { antigen } \\
(\mathrm{n}=467)\end{array}$ & $\begin{array}{l}\text { Positive }(\%) \text { to } \\
\text { BVDV } \\
\text { antibody } \\
(\mathrm{n}=323)\end{array}$ & $\begin{array}{l}\text { Co-infection } \\
(\%) \text { to BVDV } \\
\text { and } N . \text { caninum } \\
(\mathrm{n}=469)\end{array}$ \\
\hline $\begin{array}{cl}\text { Feeding practice } \\
\text { - } \quad \text { Zero grazed } \\
\text { - } \quad \text { Not zero grazed } \\
\text { P-value }\end{array}$ & $\begin{array}{l}211(44.9) \\
259(55.1)\end{array}$ & $\begin{array}{l}77 / 211 \\
88 / 259 \\
0.570\end{array}$ & $\begin{array}{l}(36.5) \\
(33.9)\end{array}$ & $\begin{array}{ll}81 / 211 & (38.4) \\
88 / 256 & (34.4) \\
0.369 & \end{array}$ & $\begin{array}{ll}58 / 140 & (41.3) \\
91 / 183 & (49.7) \\
\mathbf{0 . 0 8 4} & \end{array}$ & $\begin{array}{l}41 / 210(19.5) \\
46 / 259(17.8) \\
0.643\end{array}$ \\
\hline $\begin{aligned} & \text { Lending animals } \\
& \text { - } \text { No } \\
& \text { - } \text { Yes } \\
& P \text {-value } 1\end{aligned}$ & $\begin{array}{l}432(92.4) \\
38(7.6)\end{array}$ & $\begin{array}{l}144 / 433 \\
21 / 37 \\
\mathbf{0 . 0 0 4}\end{array}$ & $\begin{array}{r}(33.3) \\
(56.8)\end{array}$ & $\begin{array}{l}\text { 149/430 (34.6) } \\
20 / 37 \quad(54.1) \\
\mathbf{0 . 0 1 8}\end{array}$ & $\begin{array}{l}138 / 229(46.2) \\
11 / 24 \quad(45.8) \\
0.883\end{array}$ & $\begin{array}{ll}75 / 432 & (17.4) \\
12 / 37 & (32.4) \\
0.023 & \end{array}$ \\
\hline $\begin{array}{l}\text { New milking cow } \\
\text { introduced to farm } \\
\text { - No } \\
\text { - Yes } \\
\quad \text { P-value } 1\end{array}$ & $\begin{array}{l}113(32.5) \\
317(67.5)\end{array}$ & $\begin{array}{l}42 / 152 \\
123 / 316 \\
\mathbf{0 . 0 1 3}\end{array}$ & $\begin{array}{l}(27.3) \\
(38.9)\end{array}$ & $\begin{array}{l}\text { 69/154 (54.4) } \\
100 / 315(31.8) \\
0.004\end{array}$ & $\begin{array}{l}31 / 79 \quad(39.2) \\
118 / 244(48.4) \\
0.196\end{array}$ & $\begin{array}{l}21 / 153(13.7) \\
66 / 316(20.9) \\
0.058\end{array}$ \\
\hline $\begin{array}{l}\text { New calf introduced to the } \\
\text { farm } \\
\begin{array}{l}\text { - No } \\
\text { - } \quad Y e s \\
\\
\quad \text { P-value } 1\end{array}\end{array}$ & $\begin{array}{l}374(79.6) \\
96(20.4)\end{array}$ & $\begin{array}{l}143 / 374 \\
22 / 96 \\
0.005\end{array}$ & $\begin{array}{c}(38.2) \\
(22.9)\end{array}$ & $\begin{array}{l}\text { 148/371 (39.9) } \\
21 / 96 \quad(21.9) \\
\mathbf{0 . 0 0 1}\end{array}$ & $\begin{array}{l}105 / 238(44.1) \\
44 / 85 \quad(51.8) \\
0.444\end{array}$ & $\begin{array}{ll}72 / 373 & (19.3) \\
15 / 96 & (15.6) \\
0.414 & \end{array}$ \\
\hline $\begin{array}{l}\text { Community pastures } \\
\text { utilized } \\
\begin{array}{l}\text { - No } \\
\text { - Yes } \\
\quad \text { P-value } 1\end{array}\end{array}$ & $\begin{array}{l}189(41.2) \\
281(59.8)\end{array}$ & $\begin{array}{l}59 / 189 \\
106 / 281 \\
\mathbf{0 . 1 4 7}\end{array}$ & $\begin{array}{l}(31.2) \\
(37.7)\end{array}$ & $\begin{array}{l}76 / 189(40.2) \\
93 / 278(33.5) \\
\mathbf{0 . 1 3 6}\end{array}$ & $\begin{array}{ll}99 / 127 & (52.0) \\
83 / 196 & (42.4) \\
\mathbf{0 . 1 2 6} & \end{array}$ & $\begin{array}{l}32 / 188(17.0) \\
55 / 281(18.5) \\
0.470\end{array}$ \\
\hline $\begin{array}{l}\text { Dairy cows have contact } \\
\text { with pigs } \\
\begin{array}{l}\text { - No } \\
\text { - Yes } \\
\quad \text { P-value } 1\end{array}\end{array}$ & $\begin{array}{l}451(96.0) \\
19(4.0)\end{array}$ & $\begin{array}{l}154 / 451 \\
11 / 19 \\
\mathbf{0 . 0 3 4}\end{array}$ & $\begin{array}{l}(34.2) \\
(57.9)\end{array}$ & $\begin{array}{l}157 / 449(35.0) \\
12 / 18 \\
\mathbf{0 . 0 0 6}\end{array}$ & $\begin{array}{l}144 / 306(47.1) \\
5 / 17 \quad(29.4) \\
0.315\end{array}$ & $\begin{array}{ll}79 / 450 & (17.6) \\
8 / 19 & (42.1) \\
0.007 & \end{array}$ \\
\hline $\begin{array}{l}\text { Dairy cows have contact } \\
\text { with dogs } \\
\text { - No } \\
\text { - Yes } \\
\quad \text { P-value }{ }^{1}\end{array}$ & $\begin{array}{l}298(63.4) \\
172(36.6)\end{array}$ & $\begin{array}{l}\text { 95/298 } \\
70 / 172 \\
\mathbf{0 . 0 5 4}\end{array}$ & $\begin{array}{l}(31.8) \\
(40.7)\end{array}$ & $\begin{array}{l}110 / 297(37.0) \\
59 / 170 \quad(34.7) \\
0.614\end{array}$ & $\begin{array}{ll}89 / 202 & (44.1) \\
60 / 121 & (49.6) \\
0.282 & \end{array}$ & $\begin{array}{l}46 / 297(15.5) \\
41 / 172(23.8) \\
\mathbf{0 . 0 2 4}\end{array}$ \\
\hline $\begin{array}{l}\text { Location of whelping areas } \\
\text { - Kennel } \\
\text { - Compound/ } \\
\text { feed-store } \\
\text { P-value } 1\end{array}$ & $\begin{array}{l}196(41.7) \\
274(58.3)\end{array}$ & $\begin{array}{l}84 / 274 \\
81 / 196 \\
\\
\mathbf{0 . 0 1 7}\end{array}$ & $\begin{array}{l}(30.7) \\
(41.3)\end{array}$ & $\begin{array}{l}112 / 274(40.9) \\
57 / 193 \quad(29.5) \\
\mathbf{0 . 0 1 2}\end{array}$ & $\begin{array}{ll}91 / 193 & (47.2) \\
58 / 130 & (44.6) \\
0.868 & \end{array}$ & $\begin{array}{l}48 / 273(17.6) \\
39 / 196(19.9) \\
0.512\end{array}$ \\
\hline
\end{tabular}

${ }_{1}^{1}$ Bold P-values indicate those meeting the criteria for multivariable modeling $(\mathrm{p}<0.15)$ 
Conversely, smaller proportions of cattle were positive for $N$. caninum $(22.9 \%)$ and BVDV antigen $(21.9 \%)$ in farms that introduced new calves versus those that did not. Over half (59.8\%) of the farmers indicated that they utilized community pastures to feed their cattle, where they could possibly contact other dairy cattle, and this variable met the cut-off for univariable associations with $N$. caninum, and BVDV antigen and antibody seroprevalence.

Cattle coming into direct contact with pigs was reported on $4.0 \%$ of farms, and was a significant univariable risk factor for BVDV antigen seropositivity. A similar observation was made for cattle on farms where farmers allowed cattle to come into direct contact with dogs $(36.6 \%$ of farms), being positively associated with seroprevalence to $N$. caninum. Furthermore, farms that had a designated kennel for bitches to whelp in (41.7\%) had a lower proportion $(30.7 \%)$ of cattle testing positive to $N$. caninum but higher proportion $(40.9 \%)$ testing positive to BVDV antigen compared to if the dogs were allowed to whelp outside the kennel in the feed storage area or within the farm compound.

Table 4. Odds Ratios (OR) and 95\% confidence interval of OR (95\% CIOR) from the final model for risk factors associated with seropositivity of Neospora caninum, in 469 dairy cattle on 158 smallholder dairy farms in Kenya in 2016-17

\begin{tabular}{|c|c|c|c|}
\hline Variables & OR & $95 \%$ CIOR & P-value \\
\hline \multicolumn{4}{|l|}{ Milking cows introduced to the farm } \\
\hline - Yes & 2.1 & $1.4-3.4$ & 0.001 \\
\hline Lending cattle & & & \\
\hline - No & Baseline & & \\
\hline - Yes & 3.0 & $1.4-7.1$ & 0.006 \\
\hline \multicolumn{4}{|l|}{ New calf introduced to the farm } \\
\hline - No & Baseline & & \\
\hline - Yes & 0.35 & $0.20-0.62$ & $<0.001$ \\
\hline Farm dogs have access to aborted fetuses & A & A & 0.816 \\
\hline Location of whelping area & A & A & 0.150 \\
\hline \multicolumn{4}{|l|}{ Farm dogs have access to aborted fetus } \\
\hline $\mathrm{X}$ Location of whelping area interaction & B & B & 0.035 \\
\hline
\end{tabular}

A main effect variable which are part of an interaction, so coefficients of the main effects are best reported using a graph ${ }^{B}$ interaction variable which has cross-tabulated categories for main effects

\section{Multivariable risk factor analyses}

Five farm-level factors were shown as important risk factors for $N$. caninum antibody seropositivity in the final model. Cattle belonging to farmers that had bought and introduced cows to their farms in the last 12 months, and farmers that lent animals out to other farmers when they incurred feed shortages were associated with increased odds of testing positive for $N$. caninum. Cattle belonging to farmers that bought and introduced calves in the last 12 months of the study were associated with lower odds of infection than farmers that had not introduced any calves. Farms whose bitches had no designated whelping area and farms where dogs had access to aborted bovine fetuses were part of a significant interaction in this model. The results in Table 4 for these last two variables are not 
shown since interaction variables are best communicated with a figure because showing one variable's coefficients or odds ratios are misleading without taking into account the other variable coefficients or odds ratios. Also note that the P-values of the main effects of an interaction can change from being significant without the interaction variable to becoming non-significant with the significant interaction variable in the model.

In Figure 1, cattle on farms whose bitches had no designated whelping area (no kennel) were nearly three times more likely to test seropositive for N. caninum when farmers allowed their dogs to access and eat aborted fetuses, compared to cattle owned by farmers who did not allow their dogs to access and eat aborted fetuses. Conversely, when dogs were kept in kennels, there was no difference in $N$. caninum seroprevalence when farmers did or did not allow their dogs to access and eat aborted fetus or fetal membranes.

When the model was fit incorporating BVDV as a risk factor (due to its ability for immunosuppression), the odd ratios of the above predictors and the interaction term changed very little. Furthermore, there was little evidence that BVDV was an important confounder in the model, with $\mathrm{p}=0.317$. Therefore, the described model without BVDV was considered the final model for $N$. caninum seropositivity.

The Pearson goodness-of-fit test for this final model without BVDV showed that the model fit the data well $(p=0.58)$. One covariate pattern was found to be highly influential because all 12 cattle in the covariate pattern were from farms that: were lending animals, had introduced milking cows and had no designated birthing area for their bitches. When observations with this covariate pattern were left out of the model, coefficients for all the predictors increased substantially, with the highest change recorded in the coefficient for lending animals. Therefore, the observations were retained in the final model, albeit with a note of caution for interpretation.
The pseudo $\mathrm{R}^{2}$ for the final N. caninum model was 0.072 .

For the BVDV antigen multivariable mixed logistic model analysis, cattle on farms where they had direct contact with pigs had six times higher odds of testing positive for the antigen, compared to farms that did not allow this contact, while accounting for clustering of cattle within farms (Table 5). Cattle on farms that had bought and introduced open heifers, and farms where bitches had no designated birthing place, were associated with lower odds of testing positive for BVDV antigen. In this multivariable model, the three categories of age would not remain in the final model because of the extra degree of freedom, and therefore age of the animal tested was dichotomised at a cut-off point of 5.6 years since the mean was 5.6. When age was dichotomised, it remained significant in the final model and formed two significant interactions. On farms where no visiting dairy farmer entered the cow shed in the last year, older animals (over 5.5 years old) had a higher probability of testing seropositive for BVDV antigen than younger animals (Figure 2). Conversely, on farms where visiting farmers entered the cow shed in the last year, there was no difference in BVDV antigen probability by age. In the second interaction variable, when cattle were older than 5.5 years, the odds of testing seropositive for BVDV antigen was lower when the farmers had introduced a new calf to the farm in the last year than when farmers had not introduced new calves (Figure 3). Conversely, when cattle were younger, the odds of testing seropositive for BVDV antigen was no different when farmers did or did not introduce a new calf in the last year.

There was moderate clustering of cattle within a farm in this final BVDV antigen model, indicated by an intra-class correlation of $27.4 \%$ for cattle within farms, confirming the need to control for clustering of cattle within farms. The Pearson goodness-of-fit showed that the model fit the data well ( $p=0.265)$. For this model, the residuals at the farm level were normally distributed and the model was adopted as such. The pseudo $\mathrm{R}^{2}$ for the final BVDV antigen model was 0.17. 


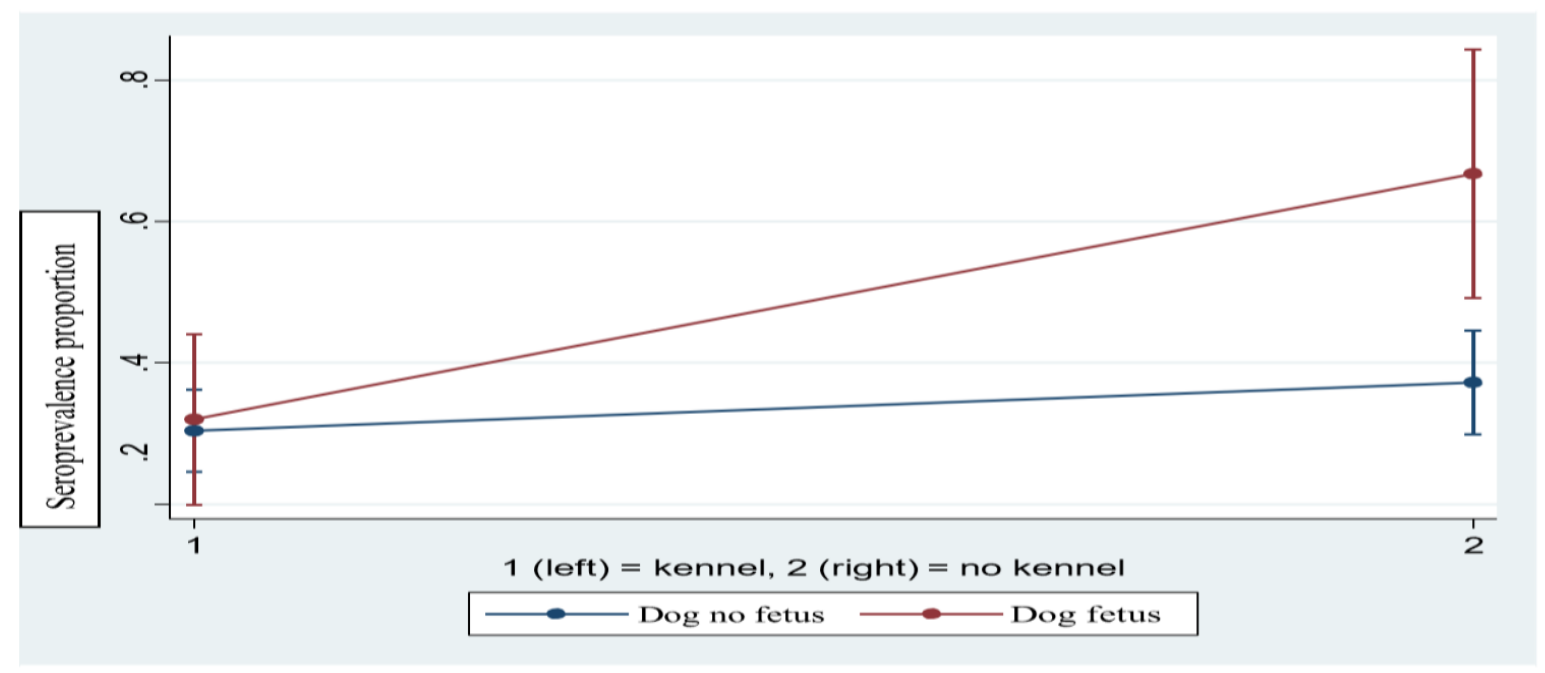

Figure 1. Interaction plot of birthing areas for bitches (kennel/no kennel) and dogs eating aborted fetuses (dog fetus/no fetus) in the final risk factor model for $N$. caninum seroprevalence in 470 dairy cattle on 158 smallholder dairy farms in Kenya in 2016-17

Table 5. Odds Ratios (OR) and 95\% confidence interval of ORs $(95 \%$ CIOR) from the final model for risk factors associated with seropositivity for bovine viral diarrhoea virus (BVDV) antigen in 467 dairy cattle on 158 farms in Kenya in 2016-17

\begin{tabular}{|c|c|c|c|}
\hline Variables & OR & $95 \%$ CIOR & P-value \\
\hline \multicolumn{4}{|l|}{ Dairy cows have contact with pigs } \\
\hline - No & Baseline & & \\
\hline - Yes & 6.1 & $1.3-29.2$ & 0.022 \\
\hline $\begin{array}{l}\text { Open heifers introduced to the farm } \\
\text { - No }\end{array}$ & & & \\
\hline - Yes & A & A & $<0.001$ \\
\hline \multicolumn{4}{|l|}{ Location of whelping area } \\
\hline - Kennel & Baseline & & \\
\hline - Cow compound/feed storage & 0.37 & $0.20-0.71$ & 0.003 \\
\hline Age of the tested animal (dichotomised) & A & A & $<0.005$ \\
\hline Other dairy farmers accessing cowshed & A & A & 0.600 \\
\hline $\begin{array}{l}\text { Age of the tested animal } X \text { Other dairy farmers } \\
\text { accessing cowshed interaction }\end{array}$ & B & B & 0.008 \\
\hline Open heifer introduced to farm & c & c & 0.586 \\
\hline $\begin{array}{l}\text { Age of tested animal X Open heifer introduced to the } \\
\text { farm interaction }\end{array}$ & D & D & 0.002 \\
\hline
\end{tabular}

AandC variables which are part of an interaction so coefficient of main effects is best reported using a graph

BandD interaction variables which have many cross-tabulated categories for main effects (not shown), so the coefficients are best reported using a graph 
The BVDV antibody multivariable logistic model revealed that being a cow was associated with over 11 times higher odds of testing seropositive over being a nulliparous heifer when all the other factors were held constant (Table 6). In this multivariable model, the three categories of parity would not remain in the final model because of the extra degree of freedom, and therefore parity of the animal tested was dichotomized at a cut-off point of nulliparous heifer versus a cow (parity $\geq 1$ ), which had a higher OR than when the mean parity was used as a cut-off. Cattle on farms feeding on community pastures, and cattle on farms that allowed dairy cattle contact with pigs were associated with lower odds of testing positive for BVDV antibody compared to those cattle on farms that did not allow such contact. The Pearson goodness-of-fit showed that the model fit the data well $(p=0.13)$. There were only nine covariate patterns in this model and thus dropping any of them would have had a substantial influence on the coefficients of the predictor variables. The pseudo $\mathrm{R}^{2}$ of the final BVDV antibody model was 0.12 .

When risk factors for co-infection with $N$. caninum antibodies and BVDV antibodies and/or antigen were assessed (Table 7), parity was the only cowlevel predictor found to be a risk factor (nulliparous cattle had lower odds of co-infection compared to cows with 3 or fewer parities and cows with 4 or more parities). Farm-level risk factors in the final model included direct contact of dairy cattle with dogs, direct contact of dairy cattle with goats, and introduction of new milking cows. The Pearson goodness-of-fit showed that the model fit the data well $(p=0.20)$. The pseudo $\mathrm{R}^{2}$ for the model was 0.07 . Two covariate patterns were influential but not outlying, and they were left in the model since dropping them meant dropping 76 observations.

Table 6. Odds Ratios (OR) and 95\% confidence interval of ORs (95\% CIOR) from a final model for risk factors associated with seropositivity for bovine viral diarrhoea virus (BVDV) antibodies in 323 dairy cattle on 158 smallholder farms in Kenya in 2016-17

\begin{tabular}{cllc}
\hline Variable -Antibody titres & OR & $95 \%$ CIOR & P-value \\
\hline Parity & & & \\
$\bullet \quad$ Nulliparous heifers & Baseline & $4.8-29.1$ & $<0.001$ \\
$\bullet \quad$ Cow $(\geq 1$ parity) & & & \\
Dairy cows have contact with pigs & Baseline & & \\
$\bullet \quad$ No & 0.35 & $0.13-0.98$ & 0.045 \\
$\bullet \quad$ Yes & Baseline & & \\
Community pasture utilized & 0.58 & $0.34-0.95$ & 0.032 \\
$\bullet \quad$ No & & & \\
- Yes & &
\end{tabular}




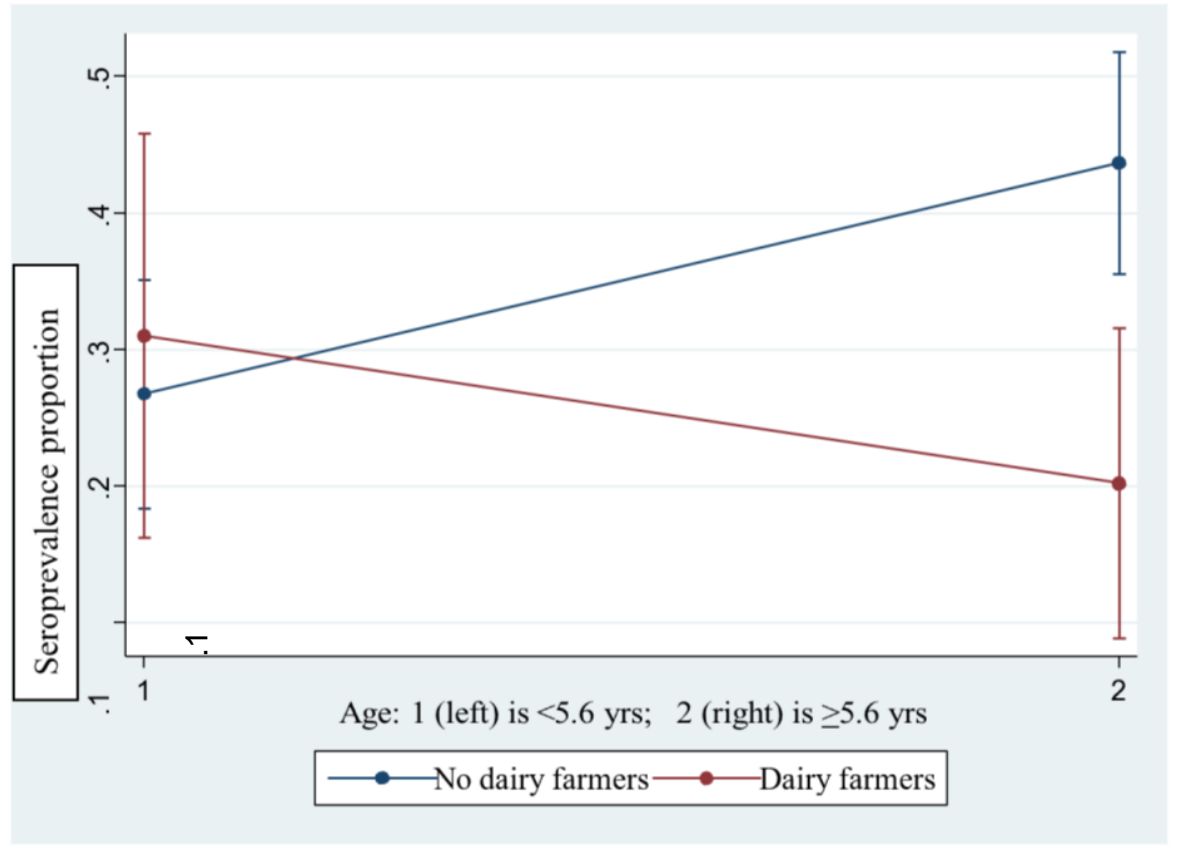

Figure 2. Interaction plot between age of the test animals and other dairy farmers accessing the cow shed (Dairy farmers/No dairy farmers) in the final risk factor model for Bovine Viral Diarrhoea Virus antigen seroprevalence in 467 dairy cattle on 158 farms in Kenya in 2016-17

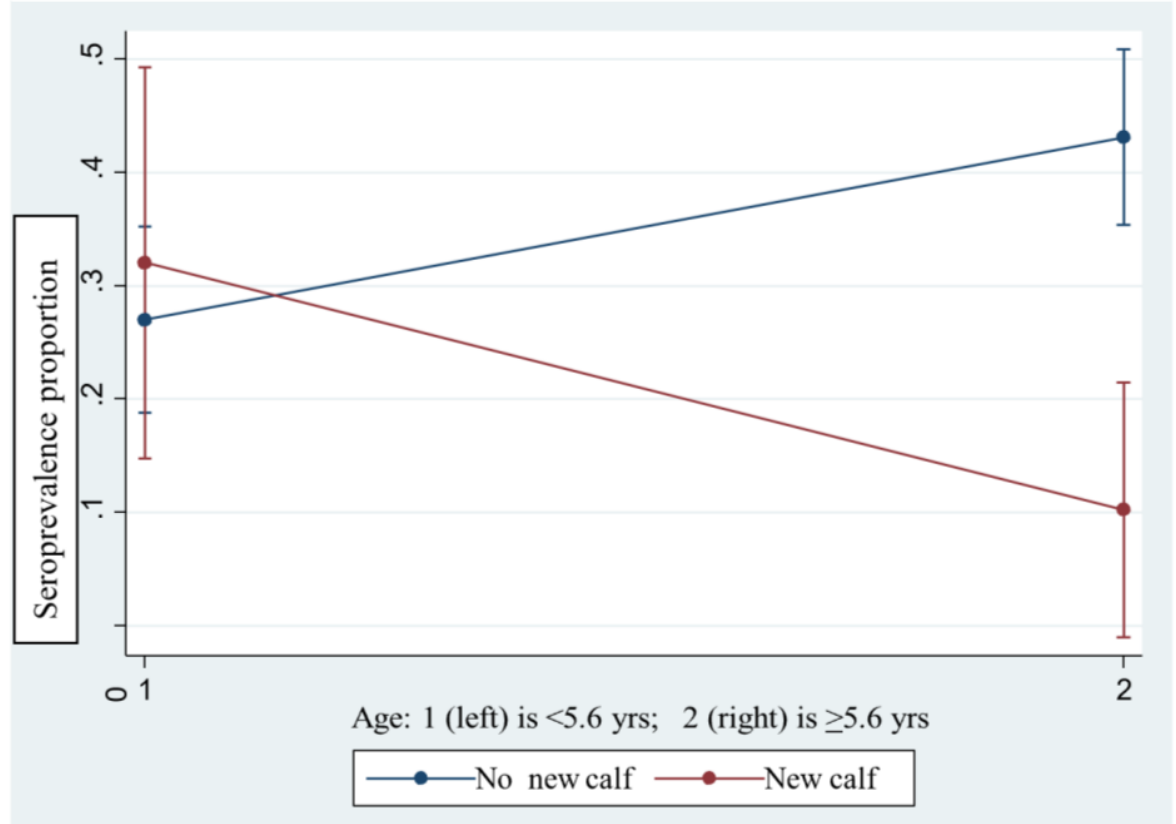

Figure 3. Interaction plot between age of the test animals and introducing new calves into the farms in the final risk factor model for Bovine Viral Diarrhoea Virus antigen seroprevalence in 467 dairy cattle on 158 farms in Kenya in 2016-17 
Table 7. Odds Ratios (OR) and 95\% confidence interval of OR (95\% CIOR) from a final model for risk factors associated with seropositivity for Neospora caninum and bovine viral diarrhoea virus (BVDV) co-infection in 469 dairy cattle on 158 farms in Kenya in 2016-17

\begin{tabular}{|c|c|c|c|}
\hline Variable & OR & $95 \%$ CIOR & P-value \\
\hline Parity & & & $0.004^{\mathrm{A}}$ \\
\hline$\bullet 0$ & Baseline & & \\
\hline - $\quad \geq 1$ but $\leq 3$ & 3.0 & $1.2-7.4$ & 0.015 \\
\hline$\cdot \quad>3$ & 4.3 & $1.6-11.4$ & 0.003 \\
\hline \multicolumn{4}{|c|}{ Dairy cows have contact with dogs } \\
\hline - No & Baseline & & \\
\hline - Yes & 1.7 & $1.1-2.7$ & 0.037 \\
\hline \multicolumn{4}{|c|}{ Dairy cows have contact with goats } \\
\hline - No & Baseline & & \\
\hline - $\quad$ Yes & 2.4 & $1.4-4.3$ & 0.002 \\
\hline \multicolumn{4}{|c|}{ New milking cow introduced to the farm } \\
\hline - No & Baseline & & \\
\hline - Yes & 1.8 & $1.1-3.0$ & 0.035 \\
\hline
\end{tabular}

A Global P-value

\section{Discussion}

Our study is the first of its kind to test for both BVDV antigen and antibody, along with $N$. caninum antibody, in a random sample of cattle on smallholder dairy farms in Kenya. Therefore, the study has enabled the estimation of the seroprevalence not only of these pathogens individually, but also their co-infection prevalence. Similarly, the study also enables the determination of risk factors not only of these pathogens individually, but also their coinfection. These results are discussed within the following sub-sections.

\section{Neospora caninum}

Worldwide prevalence of Neospora caninum has been estimated to range between $0.5 \%$ and $76.9 \%$ (Bartels et al., 2006; Cedeño and Benavides 2013). Therefore, our result in Kenya of 35.1\% would appear to be in the middle of these estimates. In Kenya, N. caninum seroprevalence has been recorded in dairy cattle on large-scale farms in the Rift Valley area (Okumu, 2019) with a seroprevalence of $25.6 \%$. This research, being a second study carried out in Kenya on N. caninum, confirms the threat of this under-documented disease in Kenya, and likely many other developing countries.

Regarding significant risk factors associated with $N$. caninum seropositivity, farms that lent or introduced milking cows were associated with higher odds of $N$. caninum compared to those that kept a closed herd (Table 4). In Ethiopia (Asmare et al., 2014), purchasing animals for replacement raised the probability of acquiring $N$. caninum infection by two times. This association emphasises the importance of biosecurity measures (e.g. quarantine until a negative $N$. caninum test result is obtained) to prevent and/or reduce introduction of infected animals into farms. Furthermore, while the majority of new infections for $N$. caninum are from vertical transmission in utero, horizontal spread is not uncommon through consumption of oocysts shed by canids (Dubey et al., 2007), and therefore movement of cattle to other farms or community pastures could increase the risk of exposure to these oocysts. There is need to educate farmers on the dangers of having animals move freely between farms and what they can do to reduce this risk. 
In a significant interaction term in our study, cattle on farms with bitches that had no designated whelping area had 3 times higher odds of testing seropositive for N. caninum when farmers allowed their dogs to access and eat aborted fetuses, compared to cattle owned by farmers who did not allow their dogs to access and eat aborted fetuses. Conversely, when dogs were kept in kennels, there was no difference in $N$. caninum seroprevalence when farmers did or did not allow their dogs to access and eat aborted fetus. The absence of birthing kennels on some farms could be taken to mean that these dogs were free-roaming or were chained in a spot around the compound, and thus, their feces could in turn contaminate the cattle environment. These two factors together synergistically potentiate the likelihood of cattle testing seropositive on these farms, but preventing dogs from defecating in the compound, feeders, water sources and pastures are among the major ways suggested to curtail new cattle infections and to keep susceptible animals free of N. caninum (Silva and Machado, 2016). Using correct placenta disposal methods that limit them from being eaten by canids has been found to lower the prevalence of $N$. caninum in dairy cows (Bruhn et al., 2013). However, in our study, the placenta disposal method was not significantly associated with $N$. caninum seropositivity, perhaps because there were few farms $(5.5 \%)$ that used correct placenta disposal methods (incineration or burying in a deep pit).

Introducing milking cows into a farm was an important risk factor for $N$. caninum seroprevalence, but introducing new calves into the farm was an important protective factor against $N$. caninum seroprevalence. As most farmers in this area of Kenya are resourceconstrained and are still faced with the problem of replacement heifers, there is a preference for purchasing weaned heifer calves and raising them to adulthood over purchasing pregnant heifers or adult cows which would be expensive. It may be possible that when calves are purchased, those calves do not survive to become pregnant and then have an abortion that leads to horizontal spread, or give birth to a vertically infected calf. Conversely, purchased infected adult cows could quickly lead to horizontal or vertical transmission when those cows become pregnant. If the purchased calves are infected bull calves, they cannot spread N. caninum vertically, and would only contribute to horizontal spread if the animal dies and part of it is consumed by canids. For both these reasons, purchased calves could appear to be protective, even though purchasing animals would generally be considered a risk factor for spread of infections.

\section{Bovine viral diarrhoea virus}

The overall apparent prevalence of BVDV antibodies in cattle in this study area was $47.1 \%$. As there was no record of vaccination against BVDV being carried out in this study area, the presence of antibodies likely indicated a natural exposure to BVDV in the past. These prevalences are substantially higher than in indigenous calves tested in western Kenya, where $19.8 \%$ and $0 \%$ were positive for antibody and antigen, respectively (Callaby et al., 2016). However, in Rift Valley, Kenya, an antibody prevalence to BVDV in non-indigenous dairy cows of $79.1 \%$ was recorded (Okumu et al., 2019). In Zebu cattle in the Coastal area of Kenya, a $45.8 \%$ BVDVantibody seroprevalence was recorded (Kenyanjui et al., 1994). On dairy farms in Kakamega, Makueni and Nandi Counties of Kenya, antibody seroprevalences were $52.3 \%$ and $24.1 \%$ for BVDV and N. caninum, respectively (Olum et al., 2020). Since BVDV is easily transmitted between cattle through body secretions, and BVDV antibodies developing from transient infections can remain in circulation for long periods of time (Lindberg and Houe, 2005), it was not surprising that the prevalence of BVDV antibodies approached or exceeded these other reports.

There is limited documentation of BVDV antigen seroprevalence in cows in Kenya. The overall apparent prevalence of BVDV antigen in cattle in this study area was $36.2 \%$. Of the 163 cattle testing positive for BVDV antigen and having an antibody test result, $49.7 \%$ were also BVDV antibody positive, suggesting that at least half of the antigen-positive animals were transiently infected (TI). The remaining 50.3\% (82/163) were either transiently (early stage before antibodies develop) or persistently infected (PI). Of the 470 animals sampled, there is evidence that $17.4 \%$ (82/470) were potentially PIs. 
Having a $17.4 \%$ of cattle as potential PIs was very surprising. Previous estimates of BVDV antigen in Kenyan and Ethiopian dairy herds found 0\% and $0 \%$ of cows and calves positive for BVDV antigen (Callaby et al., 2016; Yitagesu et al., 2021). However, our BVDV test results may be partly a function of test cross-reaction with classical swine fever virus (CSFV) or border disease virus (BDV) because these viruses are found in Kenya and many of the study farms had goats and pigs. CSFV is in the same pestivirus family as BVDV, BVDV can infect pigs, and others have found cross-reaction of CSFV on BVDV tests (Gatto et al., 2018). Furthermore, there is recent preliminary evidence for possible cattle infection with CSFV in China and India (Giangaspero et al., 2017). Border disease virus, which is another virus in the same Pestivirus genus as BVDV and CSFV, has also been known to infect cattle (Braun et al., 2019). Project funding did not include testing for CSFV or BDV. Therefore, the BVDV prevalence reported for this study should be referred to as an apparent prevalence, based on the test results obtained with the BVDV tests, and they should be interpreted with caution.

In terms of risk factors for BVDV antigen, direct contact of dairy cattle with pigs was a significant risk factor in the final model (Table 5), reinforcing the prevalence concern mentioned above. Farmers that kept a few pigs on the farm would frequently have the pig sty constructed next to the cow shed, allowing very close contact of these two species of animals at all times. BVDV has recently been found in sheep, goats, pigs, buffaloes and other wildlife, although the role of these species in BVDV transmission to and from cattle has not been experimentally proven (Khodakaram-Tafti and Farjanikish, 2017). Future research should explore the relationship between BVDV and CSFV in cattle and pigs in Kenyan SDFs.

Age of the test animals formed important interactions with other variables in the BVDV antigen model. On farms where no visiting dairy farmer entered the cow shed in the last year, older animals had a higher probability of testing seropositive for BVDV antigen than younger animals (Figure 2). Also, older animals had a reduced probability of testing positive for BVDV antigen when the farmers had introduced new calves to the farms but not when farmers had not introduced new calves (Figure 3). In Ireland, BVDV was reported to have higher seroprevalence in adult cows than in calves less than 9 months old (Sayers et al., 2015). An increase in seroprevalence from $10 \%$ in heifers to $75-85 \%$ in cows aged 10 years has been reported, possibly due to an increase in cumulative risk of having been exposed over time (Daves et al., 2016). Farmers that indicated having other farmers visit and access their cow sheds tended to belong to local dairy-based self-help groups that were organizing some training sessions on dairy management. Future research is recommended to explore these possible relationships further.

The present study also indicated that buying and introducing open heifers and calves into new farms were significant in the final model and were associated with reduced risk of BVDV antigen seropositivity (Table 5). This result could be explained by the fact that younger cattle had a lower probability of being infected compared to older milking cows, and thus the older cattle would have higher odds of testing positive if they were to be tested at purchase. This result emphasises the need for testing purchased animals (if purchased animals are needed) as one of the major ways of keeping specific-pathogenfree herds that way. In this study area, it is a common practice to exchange animals through purchase or lending without any testing for any infections or executing any quarantine practice. Purchase and exchange of animals has been identified as a classic risk for the occurrence and dissemination of infectious organisms (Fèvre et al., 2006). In a study in Brazil, the only farms that did not have any seropositive animals were those that did not have a history of purchasing or exchanging animals (Marques et al., 2016).

For the BVDV antibody seropositivity final model, cows were nearly 12 times more likely to test seropositive for BVDV antibodies then heifers (Table 6). Our results differ with what was obtained in Danish dairy herds by Houe and Meyling (1991) who reported that the risks of BVDV infection were approximately similar in all age groups. The dissimilarities between these studies may be due to farm size and the fact that our study was carried out in smallholder settings where cows are rarely culled for their age or low 
production, and therefore can remain on the farm for as long as the farmer will have them (the oldest cow in the study being 17 years old). Age as a risk factor is probably due to the fact that BVDV antibodies from infections (versus maternal antibodies) can last a long time, and perhaps even a lifetime, therefore, the older the animal is, the higher the probability that it has been infected during its lifetime (Garoussi et al., 2009).

This BVDV antibody model also found that direct contact between dairy cattle and pigs was protective towards BVDV antibody seropositivity. This result would indicate that cattle on farms without pigs were more likely to be BVDV antibody positive than cattle on farms with pigs. It is unclear why this result was found. One speculative explanation for this finding could be that CSF is spread from pigs to cattle on farms with both species, and the CSFV may be offering some protection against BVDV infection. Future research could explore this hypothesis.

A surprising factor that was found to be protective in this BVDV antibody model was possible contact of dairy cattle with other dairy cows on community pastures. It is unclear why this result was found. In this area in Kenya, community pastures were defined as either grazing along the roadsides, in school and/or church yards, or in portions of open land in the forest, and the explanation could be related to this mixture of types of community pasture. It was noted that animals that were grazed in the school and/or church yards were driven to the yards in the morning and collected in the evening, and there was a fee attached to grazing in these areas that the farmers were required to pay. This type of community pasture grazing usually limited the number of farmers grazing their cattle in these areas and would therefore lead to limited or no contact with other dairy cattle. Cattle driven into the forest were mainly left there for longer periods of time, with possible exposure to other cattle or wild ruminants. Farmers that reported constantly grazing their cattle in the forest usually had a few cows that were considered "zero-grazed" and were usually left behind in the homestead. Those cattle not going to the community pasture were the ones that were tested, and if these two cohorts from a farm were not commingled, this factor could appear protective. With the different types of community pasture possible, and the different exposures related to each type, detailed future research should differentiate the type of community pasture utilised to be able to more clearly identify which types present risk of infection and which types could be protective or do not present risk of infection.

\section{Bovine viral diarrhoea virus and Neospora caninum co-infection}

From our sample population, $18.2 \%(87 / 469)$ of the animals were positive for both $N$. caninum (antibodies) and BVDV (antibodies and/or antigens). An association between antibodies against $N$. caninum and BVDV was found in Swedish cattle, and this co-infection had a direct association to abortions, perhaps due to the immunosuppressive effects of BVDV increasing a host's susceptibility to other infectious agents (Björkman et al., 2000). In a previous study in Kenyan cattle, $83.3 \%$ of the N. caninum positive cattle were also positive for BVDV, and more abortions were reported in cattle that had seropositivity for more than one abortifacient pathogen compared to cattle positive for only one abortifacient pathogen (Okumu et al., 2019). Further investigation with a larger sample size in a longitudinal study would provide more evidence to confirm the impacts of this coinfection.

In terms of risk factors for N. caninum and BVDV co-infection, an OR>3 was recorded for cows between parity 1 and 3 , and also over 3 parities, compared to those that had not delivered a calf yet (Table 7). Parity was also shown as a risk factor of BVDV infection elsewhere (MuñozZanzi et al., 2003).

Dairy cattle contact with dogs was associated with an OR of 1.7, indicating that it was a risk factor for co-infection of $N$. caninum and BVDV (Table 7). Otranto et al., (2003) reported a higher seropositivity for $N$. caninum on farms with two or more dogs than on farms with one dog or none. In a study carried out in the Rift Valley part of Kenya (Okumu et al., 2016), a 17.9\% seroprevalence of $N$. caninum was reported in dogs found on farms, compared with a $0 \%$ 
prevalence in feral dogs in a study carried out 17 years ago in Kenya (Barber et al., 1997). Numerous roaming dogs were observed during the farm visits during the current study. Future research is needed to show the contribution of farm dogs and the risk of their close contact with dairy cattle, especially in cases of cross-infection with Neospora and another abortifacient pathogen.

Dairy cattle contact with goats was another risk factor to co-infection. It is known that sheep and goats can be infected by BVDV-1, BVDV-2 and border disease virus (BDV), producing similar clinical signs of BVDV infection to cattle (Kim et al., 2006). Transmission of BVDV infection between small ruminants and cattle has been demonstrated, although usually it is from cattle to sheep or goats, and cattle can become infected with BDV (Braun et al., 2019). There are also reports of N. caninum abortions in goats in Brazil ( de Oliveira Junior et al., 2020), acting as intermediate hosts in the lifecycle of N. caninum. Therefore, goats' contributions to the seroprevalence of the two pathogens in our study should not be ignored. In the study area in Kenya, small ruminants were often kept on smallholder dairy farms as a source of meat.

\section{Study Limitations and Future Research}

Serological investigations with a cross-sectional design have both advantages and disadvantages as methods to establish the prevalence and risk factors of infection. Cross-sectional studies for antibodies to pathogens provide good prevalence estimates when the pathogens and/or antibodies are persistent. For BVDV, animals are generally seropositive for at least several years after the infection (Fredriksen et al., 1999), while N. caninum infections are retained for life (Dubey et al., 2007). Therefore, a cross-sectional study for antibodies to test for BVDV and $N$. caninum should have produced relevant estimates of infection prevalence in the study area of Kenya where vaccines for these two diseases are not used. However, identifying risk factors for prevalence of infection is not as helpful as identifying risk factors for incidence of infection because prevalence is a function of both incidence and duration, complicating the interpretation of the statistical results (Dohoo et al., 2009). Future research on risk factors of incidence of infection would be helpful to tease out which prevalence risk factors are also incidence risk factors. Risk factors of incidence may also clarify some of the unexpected risk factor results.

Interpreting BVDV test results can be confusing and complicated. Given the logistics of the project, we did our best with testing for antibodies and antigens, assuming that if they were antigen positive and antibody negative, they were likely either transiently (in early stages of infection before antibodies develop) or persistently infected. However, taking a second sample a month after the first one that was BVDV antigen-positive would have been helpful to establish persistent infection, but that was logistically impossible because the test kits had to be imported into the country once all samples were taken and the number of samples to be tested known. Furthermore, where pigs and goats are kept in close proximity to cattle, the role of classical swine fever virus (Giangaspero 2017) and border disease virus (Kim et al., 2006) should be considered, in terms of study design (testing) and interpretation of results. For logistical reasons, we were unable to test our sera for these other viruses. Despite these interpretation cautions, we believe it is still useful to report these prevalence and risk factor results to inform other researchers doing research on pestiviruses in countries where all three viruses co-exist.

There were 144 samples that were not run for the BVDV antibody test after they were tested for BVDV antigen. This difference in sample numbers for BVDV testing was from a logistical problem; not enough antibody kits were available at the initial time of antigen testing. Then, a laboratory problem occurred, which meant that the 144 samples were no longer available for testing when the antibody kits did arrive. It is unlikely that a bias was introduced from the difference in sample numbers because the reason for the difference in sample numbers was not related to the purpose of the study.

The risk factor analysis of co-infections utilised an outcome variable definition that included cattle that were antibody-positive for N. caninum and antibody-positive and/or antigen-positive for BVDV. The reason for the inclusivity of the BVDV results was to ensure that we included all cattle 
exposed to BVDV, either current or historical, since we were using all cattle exposed to $N$. caninum, regardless of when they became infected. We could have defined co-infection to include just cattle that were either antibodypositive or antigen-positive for BVDV, but that would have led to a different interpretation of the results. Using only antigen-positive cattle would include only current TI cattle and PI cattle, but not previously exposed TI cattle. Using only antibody-positive cattle would include only previously exposed TI cattle. We chose to be inclusive in our definition. In the future, use of sentinel calves could help to identify the circulation of BVDV in a population (Corbett et al., 2011).

\section{Conclusion}

For the $35.1 \%$ of cattle with $N$. caninum infection, significant risk factors were lending of cattle between farms and farmers introducing milking cows to their farms, while introducing calves into the farms was a protective factor. In an interaction variable, cattle on farms whose bitches had no designated whelping area were more likely to test seropositive for $N$. caninum when farmers allowed their dogs to access aborted fetuses compared to cattle owned by farmers who did not allow their dogs to access aborted fetuses. For the $36.2 \%$ of cattle with BVDV antigen seropositivity, introducing open heifers (versus cows) and farm dogs having a designated birthing kennel were protective factors, while direct contact of cattle with pigs was a risk factor. Age was involved in two interaction variables. On farms where no visiting dairy farmer entered the cow shed in the last year, older animals had a higher probability of testing seropositive for BVDV antigen than younger animals. Similarly, older animals

\section{References}

Asmare, K., Regassa, F., Robertson, L. J., Martin, A. D., and Skjerve, E. (2013). Reproductive disorders in relation to Neospora caninum, Brucella spp. and bovine viral diarrhoea virus serostatus in breeding and dairy farms of central and southern Ethiopia. Epidemiology and Infection, 141(8), 1772-1780. doi:10.1017/S0950268812002191 appeared to have a reduced probability of testing positive for BVDV antigen when the farmers had introduced new calves to the farms but not when farmers had not introduced new calves. For the $47.1 \%$ of cattle with BVDV antibody seropositivity, age (cows versus heifers) was a risk factor while direct contact of dairy cattle with pigs and possibly with other cattle or wild ruminants on community pastures appeared to be protective factors. For the $18.5 \%$ of cattle with co-infections between $N$. caninum and BVDV antibody and/or antigen seropositivity, parity, direct contact of dairy cattle with dogs and with goats, and introducing milking cows into farms were all significant risk factors in the final model. Farmer education on these biosecurity measures is recommended, along with introduction of BVDV vaccination.

\section{Acknowledgements}

We are grateful to the primary funding program for this research, the Canadian Queen Elizabeth II Diamond Jubilee Scholarships, which are managed through a unique partnership of Universities Canada, the Rideau Hall Foundation, Community Foundations of Canada and Canadian universities. This program is made possible with financial support from the Government of Canada, provincial governments, and the private sector. We also acknowledge the large contribution made by volunteers and staff of Farmers Helping Farmers, a non-governmental organization. We acknowledge the leadership and members of the Naari Dairy Farmers Cooperative Society in Meru, Kenya, for their cooperation in the study. We thank IDEXX Inc. for providing test kits for the project. We also appreciate the data collection and entry efforts of summer students: Kelsie Goodick, Ali Frye, Ren Chamberlain and Julia Kenny.

Asmare, K., Skjerve, E., Bekele, J., Sheferaw, D., Stachurska-Hagen, T., and Robertson, L. J. (2014). Molecular identification of Neospora caninum from calf/foetal brain tissue and among oocysts recovered from faeces of naturally infected dogs in southern Ethiopia. Acta tropica, 130, 88-93. doi:10.1016/j.actatropica.2013.10.017

Barber, J. S., Gasser, R. B., Ellis, J., Reichel, M. P., McMillan, D., and Trees, A. J. (1997). 
Prevalence of antibodies to Neospora caninum in different canid populations. The Journal of parasitology, 1056-1058. doi:10.2307/3284361

Bartels, C. J. M., Arnaiz-Seco, J. I., Ruiz-SantaQuitera, A., Björkman, C., Frössling, J., Von Blumröder, D., ... and Ortega-Mora, L. M. (2006). Supranational comparison of Neospora caninum seroprevalences in cattle in Germany, The Netherlands, Spain and Sweden. Veterinary Parasitology, 137(1-2), 17-27. doi:10.1016/J.VETPAR.2005.12.016

Björkman, C., Alenius, S., Manuelsson, U., and Uggla, A. (2000). Neospora caninum and bovine virus diarrhoea virus infections in Swedish dairy cows in relation to abortion. The Veterinary Journal, 159(2), 201206. doi:10.1053/tvjl.1999.0446

Braun, U., Hilbe, M., Peterhans, E., and Schweizer, M. (2019). Border disease in cattle. The Veterinary Journal, 246, 12-20. doi: 10.1016/j.tvjl.2019.01.006.

Bruhn, F. R. P., Daher, D. O., Lopes, E., Barbieri, J. M., da Rocha, C. M. B. M., and Guimarães, A. M. (2013). Factors associated with seroprevalence of Neospora caninum in dairy cattle in southeastern Brazil. Tropical animal health and production, 45(5), 1093-1098. doi:10.1007/s11250-012-0330-y

Callaby, R., Toye, P., Jennings, A., Thumbi, S. M., Coetzer, J. A. W., Van Wyk, I. C., ... and Kiara, H. (2016). Seroprevalence of respiratory viral pathogens of indigenous calves in Western Kenya. Research in veterinary science, 108, 120-124. doi:10.1016/j.rvsc.2016.08.010

Cedeño Q, D., and Benavides B, B. (2013). Seroprevalence and risk factors associated to Neospora caninum in dairy cattle herds in the municipality of Pasto, Colombia. Revista MVZ Córdoba, 18(1), 3311-3316.

Corbett E. M., Grooms D. L., Bolin S. R., Bartlett B., Grotelueschen D. M. Use of sentinel serology in a Bovine viral diarrhea virus eradication program. Journal of Veterinary Diagnostic Investigation. 2011 May;23(3):511-5. doi: $10.1177 / 1040638711403412$
Daves, L., Yimer, N., Arshad, S. S., Sarsaifi, K., Omar, M. A., Yusoff, R.,.. and Abdullah, F. F. J. (2016). Seroprevalence of bovine viral diarrhea virus (BVDV) infection and associated risk factors in cattle in Selangor, Malaysia. Veterinary Medicine Open Journal, 1, 22-28. doi:10.17140/VMOJ-1-105

de Oliveira Junior, I. M., dos Santos Mesquita, L. E., Miranda, D. N. P., Gomes, T. A., Vasconcelos, B. K. S., Penha, L. C., ... and Varaschin, M. S. (2020). Endogenous transplacental transmission of Neospora caninum in successive generations of congenitally infected goats. Veterinary Parasitology, 284, $109191 . \quad$ doi: 10.1016/j.vetpar.2020.109191

Dohoo, I. R., Martin, S. W., and Stryhn, H. (2009). Veterinary Epidemiologic Research. VER. Inc., Charlottetown, PE, Canada.

Donahoe, S. L., Lindsay, S. A., Krockenberger, M., Phalen, D., and Ślapeta, J. (2015). A review of neosporosis and pathologic findings of Neospora caninum infection in wildlife. International Journal for Parasitology: Parasites and Wildlife, 4(2), 216-238. doi:10.1016/j.ijppaw.2015.04.002

Dubey, J. P., Schares, G., and Ortega-Mora, L. (2007). Epidemiology and control of neosporosis and Neospora caninum. Clinical microbiology reviews, 20(2), 323-367. doi:10.1128/CMR.00031-06

Fèvre, E. M., Bronsvoort, B. M. D. C., Hamilton, K. A., and Cleaveland, S. (2006). Animal movements and the spread of infectious diseases. Trends in microbiology, 14(3), 125131.doi:10.1016/j.tim.2006.01.004.

Fèvre, E. M., Bronsvoort, B. M. D. C., Hamilton, K. A., and Cleaveland, S. (2006). Animal movements and the spread of infectious diseases. Trends in microbiology, 14(3), 125131. doi: 10.1016/s0378-4320(00)00082-8

Fredriksen, B., Sandvik, T., Løken, T., and Ødegaard, S. A. (1999). Level and duration of serum antibodies in cattle infected experimentally and naturally with bovine virus diarrhoea virus. Veterinary Record, 144(5), 111-114. doi: 10.1136/vr.144.5.111 
Gatto, I. R. H., Linhares, D. C. L., de Souza Almeida, H. M., Mathias, L. A., de Medeiros, A. S. R., Poljak, Z., ... and de Oliveira, L. G. (2018). Description of risk factors associated with the detection of BVDV antibodies in Brazilian pig herds. Tropical animal health and production, 50(4), 773-778. doi: $10.1007 / \mathrm{s} 11250-017-1493-3$

Giangaspero, M., Kumar, S. K., and Zhang, S. (2017). Classical swine fever virus in cattle. Veterinary Record,181(3): 73 - 74. doi.org/10.1136/vr.j3369

Houe, H, and Meyling, A. (1991). Prevalence of Bovine Virus Diarrhoea (BVD) in 19 Danish Dairy Herds and Estimation of Incidence of Infection in Early Pregnancy. Preventive Veterinary Medicine 11, 9-16. doi:10.1016/S0167-5877(05)80040-6

Ibrahim, A. M. E., Elfahal, A. M., and El Hussein, A. R. M. (2012). First report of Neospora caninum infection in cattle in Sudan. Tropical Animal Health and Production, 44(4), 769-772. doi:10.1007/s11250-011-9963-5

Kamali, A., Seifi, H. A., Movassaghi, A. R., Razmi, G. R., and Naseri, Z. (2014). Histopathological and molecular study of Neospora caninum infection in bovine aborted fetuses. Asian Pacific Journal of Tropical Biomedicine, 4(12), 990-994. doi:10.12980/ APJTB.4.201414B378.

Kenyanjui, M., Steiger, Y., and Thorpe, W. (1994). Virus neutralizing Anitbodies to bovine herpes virus type 1 (BHV-1), bovine viral diarrhoea (BVD) and rinderpest (RPV) viruses in smallholder east African zebu cattle in coastal Kenya. Kenya Veterinarian, 18, 21-24.

Khodakaram-Tafti, A., and Farjanikish, G. H. (2017). Persistent bovine viral diarrhea virus (BVDV) infection in cattle herds. Iranian journal of veterinary research, 18(3), 154 - 163.

Kim, I. J., Hyun, B. H., Shin, J. H., Lee, K. K., Lee, K. W., Cho, K. O., and Kang, M. I. (2006). Identification of bovine viral diarrhea virus type 2 in Korean native goat (Capra hircus). Virus Research,121(1), 103-106. doi:10.1016/j.virusres.2006.04.008
Liess. B., and Moennig. V. (1990). Ruminant Pestivirus Infection in Pigs. Revue Scientifique et Technique (International Office of Epizootics) 9 (1): 151-6 Available at: https://pdfs.semanticscholar.org/2d03/bf 7f3b10aae84922c66a90c27bf0231691e3.pdf (verified 26 November 2020)

Lindberg A, and Houe, H . (2005). Characteristics in the Epidemiology of Bovine Viral Diarrhea Virus (BVDV) of Relevance to Control. Preventive Veterinary Medicine 72, 55-73. doi:10.1016/j.prevetmed.2005.07.018

Marques, A. L. A., de Oliveira Assis, A. C., Simões, S. V. D., de Lima Tolentino, M. L. D., and de Azevedo, S. S. (2016). Risk factors associated with Bovine Viral Diarrhea Virus (BVDV) infection in the semiarid of the state of Paraíba, in the northeast region of Brazil. Semina: Ciências Agrárias, 37(5), 30953105.

Muñoz-Zanzi, C. A., Hietala, S. K., Thurmond, M. C., and Johnson, W. O. (2003). Quantification, risk factors, and health impact of natural congenital infection with bovine viral diarrhea virus in dairy calves. American journal of veterinary research, 64(3), 358-365. $\underline{\text { doi.org/10.2460/ajvr.2003.64.358 }}$

Okumu, T. A., Munene, J. N., Wabacha, J., Tsuma, V., and Van Leeuwen, J. (2016). Seroepidemiological survey of Neospora caninum and its risk factors in farm dogs in Nakuru district, Kenya. Veterinary world, 9(10), 1162 doi: 10.14202/vetworld.2016.1162-1166

Okumu, T. A., John, N. M., Wabacha, J. K., Tsuma, V., and VanLeeuwen, J. (2019). Seroprevalence of antibodies for bovine viral diarrhoea virus, Brucella abortus and Neospora caninum, and their roles in the incidence of abortion/foetal loss in dairy cattle herds in Nakuru District, Kenya. BMC veterinary research,15(1), 1-6. doi: 10.1186/s12917-019-1842-8

Olum, M. O., Mungube, E. O., Njanja, J., Kidali, J., Njenga, E., Maichomo, M., and Mugambi, J. (2020). Seroprevalence of canine neosporosis and bovine viral diarrhoea in dairy cattle in selected regions of 
Kenya. Transboundary and emerging diseases, 67,

158. https://doi.org/10.1111/tbed.13429

Otranto, D., Llazari, A., Testini, G., Traversa, D., di Regalbono, A. F., Badan, M., and Capelli, G. (2003). Seroprevalence and associated risk factors of neosporosis in beef and dairy cattle in Italy. Veterinary Parasitology, 118(12), 7-18. doi:10.1016/j.vetpar.2003.10.008

Sayers, R. G., Byrne, N., O'Doherty, E., and Arkins, S. (2015). Prevalence of exposure to bovine viral diarrhoea virus (BVDV) and bovine herpesvirus-1 (BoHV-1) in Irish dairy herds. Research in Veterinary Science, 100, 21-30. doi:10.1016/j.rvsc.2015.02.011

Silva, R., and Machado, G. (2016) Canine Neosporosis: Perspectives on Pathogenesis and Management. Veterinary Medicine: Research and Reports 7, 59-70. doi.org/10.2147/VMRR.S76969

Garoussi, M. T., Haghparast, A., and Hajenejad, M. R. (2009). Prevalence of Bovine Viral Diarrhoea Virus antibodies among the industrial dairy cattle herds in suburb of Mashhad-Iran. Tropical animal health and production, 41(4), 663-667. doi:10.1007/s11250-008-9238-y

Tinsley, M., Lewis, F. I., and Brülisauer, F. (2012). Network modeling of BVD transmission. Veterinary research, 43(1), 1-9. doi:10.1186/1297-9716-43-11

Yeşilbağ, K., Alpay, G., and Becher, P. (2017). Variability and global distribution of subgenotypes of bovine viral diarrhea virus. Viruses, $9(6)$,

128. doi:10.3390/v9060128

Yitagesu, E., Jackson, W., Kebede, N., Smith, W., and Fentie, T. (2021). Prevalence of bovine abortion, calf mortality, and bovine viral diarrhea virus (BVDV) persistently infected calves among pastoral, peri-urban, and mixed-crop livestock farms in central and Northwest Ethiopia. BMC veterinary research, 17(1), 1-10. https://doi.org/10.1186/s12917-021-02798w 